\title{
(C) OPEN ACCESS \\ Long-term follow-up of survivors of childhood cancer (SIGN Clinical Guideline 132)
}

\author{
Hoong-Wei Gan, ${ }^{1,2}$ Helen A Spoudeas ${ }^{2,3}$
}

\begin{abstract}
${ }^{1}$ Developmental Endocrinology Research Group, UCL Institute of Child Health, London, UK

${ }^{2}$ The London Centre for Paediatric Endocrinology \& Diabetes, Great Ormond Street Hospital for Children NHS Foundation Trust, London, UK ${ }^{3}$ The London Centre for Paediatric Endocrinology \& Diabetes, University College London Hospitals NHS Foundation Trust, London, UK
\end{abstract}

\section{Correspondence to} Dr Hoong-Wei Gan, Developmental Endocrinology Research Group, Clinical \& Molecular Genetics Unit, UCL Institute of Child Health, 30 Guilford Street, London WC1N 1EH, UK;

hoong.gan.11@ucl.ac.uk

Received 27 October 2013 Revised 31 January 2014 Accepted 16 February 2014 Published Online First 17 March 2014

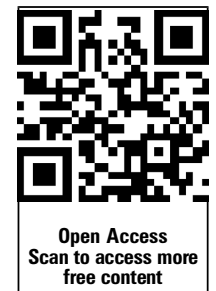

CrossMark

To cite: Gan H-W,
Spoudeas HA. Arch Dis Child
Educ Pract Ed 2014;99:
138-143.

To cite: Gan H-W, Educ Pract Ed 2014:99: $138-143$

\section{BACKGROUND}

Five-year childhood cancer survival rates have increased to $80-90 \%$ for some tumours due to intensified treatments and better supportive care imposed on an incidence stable over four decades. ${ }^{1} 2$ Between 2005 and 2012, the number of UK survivors has risen from 26000 to 33000 , or from $1: 1000$ to $1: 715$ UK adults. $^{3} 4$ However, 40\% experience chronic severe or life-threatening consequences ('late effects') of their tumour and/or its treatment. ${ }^{5}$ The recent National Cancer Survivorship Initiative (NCSI) has highlighted the unmet need in service provision for adult childhood cancer survivors, with a proposed survivorship framework and stratified care pathways modelled on $>20$ years' prior experience. $^{67}$

In March 2013, the Scottish Intercollegiate Guidelines Network (SIGN) published updated guidance on long-term follow-up of childhood cancer survivors to aid the 'identification, assessment and management of late effects' aimed at primary, secondary and tertiary healthcare practitioners. ${ }^{8}$ The Guideline Development Group (GDG) included representatives from paediatric haematology, oncology, endocrinology, reproductive medicine, cardiology, general paediatrics and general practice, as well as a survivor.

\section{PREVIOUS AND OTHER ASSOCIATED GUIDELINES}

The previous SIGN 76 guideline was published in 2004. This revision updates information on fertility preservation, cardiac late effects and patient information provision, and provides new sections on subsequent primary cancers (SPCs), bone health and metabolic syndrome. The UK Children's Cancer Study Group's (UK CCSG) best practice statement ${ }^{9}$ is a potentially valuable companion guideline for tertiary care practitioners requiring details of therapeutic regimens and their toxicity profiles to individualise care for those most affected.

\section{KEY ISSUES}

- Section 11: long-term follow-up provides a useful summary of the recommendations. It recognises the multisystemic and evolving nature of late effects over decades of survival, concluding a need for lifelong multidisciplinary follow-up (table 1). The authors suggest a three-tiered follow-up stratified by disease-related and/or treatment-related morbidity risk (table 2) and list the key multidisciplinary professionals required (box 1).

- Subsequent primary cancers (SPCs)-The British Childhood Cancer Survivor Study ${ }^{10}$ and others have shown an excess SPC risk $->50 \%$ due to gastrointestinal, genitourinary, breast and lung cancerspersisting into old age.

- Fertility-The impact of cancer treatment on the pituitary-gonadal axis, reproductive capacity and options for pretreatment fertility preservation are complex and differ between the sexes (see British Fertility Society review for a fuller discussion ${ }^{11}$ ). In boys, post-treatment sub/infertility may exist despite a normal puberty and potency. ${ }^{12}$ With intracytoplasmic sperm injection, oligospermia is no barrier to fertility preservation, while long-term spermatogenic recovery is possible. ${ }^{13}$ By contrast, pubertal delay or secondary amenorrhoea may herald sub/infertility in girls whose options are more limited. Pretreatment gonadotropin-releasing hormone analogues, ovarian transposition and oocyte collection are unproven and/or impracticable. Prepubertal children of either sex have no recommended options outside a clinical trial. Miscarriage rates are increased, but 
Table 1 Summary of SIGN recommendations on long-term follow-up of survivors of childhood cancer

\begin{tabular}{|c|c|c|c|c|}
\hline Late effect & High-risk factors & Specific late effects & Screening methods/ management & $\begin{array}{l}\text { Evidence } \\
\text { level/grade }\end{array}$ \\
\hline \multirow[t]{2}{*}{$\begin{array}{l}\text { Subsequent primary } \\
\text { cancers (SPCs) }\end{array}$} & $\begin{array}{l}\text { Genetic predisposition, eg, NF-1 } \\
\text { Radiotherapy }\end{array}$ & $\begin{array}{l}\text { Dependent on syndrome } \\
\text { Delayed presentation }>5 \text { years from treatment, at } \\
\text { edge of radiation field (eg, mediastinal radiotherapy } \\
\text { and breast SPCs) }\end{array}$ & $\begin{array}{l}\text { As per guidance for specific syndromes } \\
\text { No consensus } \\
\text { Promote healthy lifestyle behaviours }\end{array}$ & $3 / C$ \\
\hline & $\begin{array}{l}\text { Chemotherapy* (alkylating agents, } \\
\text { epipodophyllotoxins) }\end{array}$ & Increased risk of all SPCS & $\begin{array}{l}\text { No consensus } \\
\text { Promote healthy lifestyle behaviours }\end{array}$ & $3 / C$ \\
\hline \multirow[t]{4}{*}{ Sub-/infertility } & $\begin{array}{l}\text { Both sexes } \\
\quad \text { Cranial radiotherapy }\end{array}$ & $\begin{array}{l}\text { Hypogonadotropic hypogonadism (pubertal } \\
\text { arrest/ delay) }\end{array}$ & See individual sections for assessment depending on sex & 3 \\
\hline & $\begin{array}{l}\text { Pelvic radiotherapy } \\
\text { Boys }\end{array}$ & Sexual dysfunction & Consider psychological referral & $3-4 / D$ \\
\hline & $\begin{array}{l}\text { Chemotherapy* (alkylating agents) } \\
\text { Gonadal radiotherapy/ total body } \\
\text { irradiation (TBI) }\end{array}$ & $\begin{array}{l}\text { Azoospermia } \\
\text { Azoospermia } \\
\text { Hypergonadotropic hypogonadism (less likely- } \\
\text { pubertal arrest/ delay, sexual dysfunction) }\end{array}$ & $\begin{array}{l}\text { Semen analysis } \pm \text { cryopreservation, FSH, inhibin B } \\
\text { Semen analysis } \pm \text { cryopreservation, FSH, inhibin B } \\
\text { Regular pubertal assessment, LH, testosterone } \\
\pm \text { pubertal induction/ testosterone supplementation }\end{array}$ & $\begin{array}{l}3 / D \\
2 \pm 3 / D\end{array}$ \\
\hline & $\begin{array}{l}\text { Girls } \\
\text { Chemotherapy* (alkylating agents) } \\
\text { Abdominopelvic radiotherapy }\end{array}$ & $\begin{array}{l}\text { Hypergonadotropic hypogonadism (pubertal arrest/ } \\
\text { delay/ oligoamenorrhoea) } \\
\text { Hypergonadotropic hypogonadism } \\
\text { Uterine dysfunction (premature delivery, low birth } \\
\text { weight) }\end{array}$ & $\begin{array}{l}\text { Regular pubertal assessment, FSH, AMH } \\
\pm \text { pubertal induction/ female hormone replacement therapy } \\
\pm 00 \text { cyte cryopreservation if postpubertal }\end{array}$ & $3 / \mathrm{D}$ \\
\hline \multirow[t]{2}{*}{ Cardiac effects } & Chemotherapy (anthracyclines) & Congestive heart failure & $\begin{array}{l}\text { Echocardiography: Fractional shortening (FS) and ejection fraction (EF) } \\
\text { measurements }\end{array}$ & $3-4 / D$ \\
\hline & Cardiac/mediastinal radiotherapy & Cardiovascular (especially coronary artery) disease & $\begin{array}{l}2-3 \text { yearly if anthracycline dose }>250 \mathrm{mg} / \mathrm{m}^{2} \\
5 \text { yearly if anthracycline dose }<250 \mathrm{mg} / \mathrm{m}^{2} \\
\text { Treat as per regular heart failure/cardiovascular disease guidelines } \\
\text { Promote healthy lifestyle behaviours }\end{array}$ & $3 / \mathrm{D}$ \\
\hline Bone health & $\begin{array}{l}\text { Chemotherapy (glucocorticoids, high dose } \\
\text { methotrexate, } 6 \text {-mercaptopurine) } \\
\text { Cranial radiotherapy } \\
\text { Bone marrow transplantation } \\
\text { Endocrine dysfunction (GH deficiency, } \\
\text { hypogonadism, hypothyroidism) }\end{array}$ & Osteoporosis (osteonecrosis with glucocorticoids) & $\begin{array}{l}\text { Dual energy X-ray absorptiometry (DXA)/ peripheral quantitative CT/ quantitative } \\
\text { ultrasound: BMD or bone mineral content (BMC) Z-scores adjusted for age, sex } \\
\text { and height } 2 \text { years post-end of treatment } \\
\text { Serial measurements not required unless abnormal or clinical change } \\
\text { Sex steroid replacement } \\
\text { Promote healthy lifestyle behaviours }\end{array}$ & $3 / \mathrm{D}$ \\
\hline $\begin{array}{l}\text { Metabolic } \\
\text { syndrome }\end{array}$ & $\begin{array}{l}\text { ALL (especially after bone marrow } \\
\text { transplantation) } \\
\text { Brain tumours (especially after cranial } \\
\text { radiotherapy and growth hormone } \\
\text { deficiency) }\end{array}$ & $\begin{array}{l}\text { Obesity } \\
\text { Dyslipidaemia } \\
\text { Insulin resistance } \\
\text { Cardiovascular disease }\end{array}$ & $\begin{array}{l}\text { BP and BMI: Annually in all survivors } \\
\text { Fasting glucose, insulin, lipid profile: } \\
\text { 2-yearly if obese/ overweight } \\
\text { 5-yearly if normal weight } \\
\text { Treat as per regular obesity guidelines }\end{array}$ & $3-4 / D$ \\
\hline Cognitive outcomes & Cranial radiotherapy & $\begin{array}{l}\text { Cognitive decline } \\
\text { Psychosocial dysfunction }\end{array}$ & Neuropsychological assessment: Pretreatment and then annually & $3 / \mathrm{D}$ \\
\hline
\end{tabular}




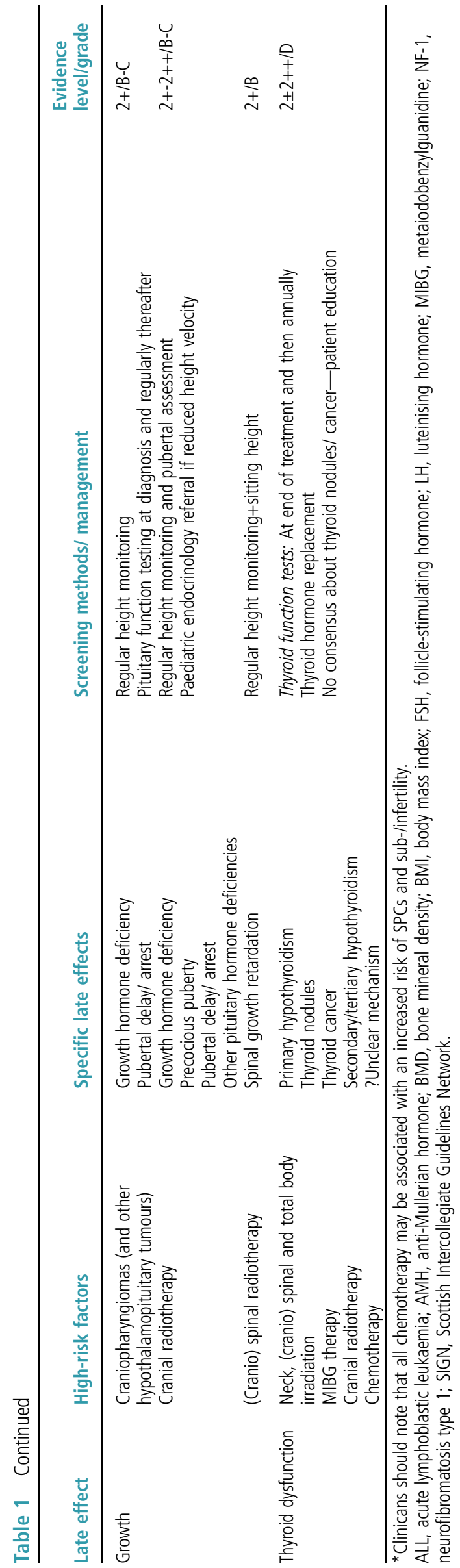

there is no excess of congenital or genetic disorders in offspring.

- Cardiac effects-Anthracycline-induced heart failure and mediastinal irradiation-induced cardiovascular disease may take years to manifest and may be additive. There is limited evidence for prophylactic ACE inhibitors or $\beta$-blockers, hence standard heart failure management is recommended.

- Bone health-Bone mineral density (BMD) as measured by DEXA is age-dependent, sex-dependent, pubertydependent and height-dependent, thus Z-scores rather than T-scores need cautious interpretation. The only evidence-based treatment for osteopenia is sex steroid replacement, although its effect on fracture risk is unknown.

- Metabolic syndrome-Studies are limited to acute lymphoblastic leukaemia (ALL) and brain tumour survivors. A normal body mass index (BMI) does not preclude insulin resistance and dyslipidaemia. ${ }^{14}$ Annual blood pressure and BMI assessments are recommended.

- Cognitivel psychosocial issues-Cranial irradiation-induced cognitive decline is age-dependent, sex-dependent and dose-dependent and compounded by adjuvant chemotherapy. ${ }^{15}$ All survivors are at increased risk of psychosocial maladjustment and warrant consideration for extra educational support.

- Growth-All new cancer patients require accurate auxology at diagnosis and regularly thereafter to adult height, although the feasibility of performing this means that low-risk patients will need monitoring in primary or secondary care. Growth velocity requires interpreting in light of puberty and hormone replacement. Growth hormone $(\mathrm{GH})$ replacement-important for bone mineralisation and childhood growth-does not increase cancer recurrence and should be substituted early particularly after spinal irradiation as it cannot fully reverse the detriment on adult height. ${ }^{16} 17$

- Thyroid dysfunction-Low-dose irradiation scatter can cause compensated and frank primary hypothyroidism years after treatment. Secondary hypothyroidism (thyroid-stimulating hormone deficiency) attributed to cranial irradiation is, in our experience, unusual outside the context of suprasellar tumours. Lifelong monitoring is recommended alongside education on self-examination.

- Information provision-Information on healthy lifestyle, support networks and the importance of long-term follow-up should be given to all survivors.

\section{UNDERLYING EVIDENCE BASE}

These SIGN guidelines represent a synthesis of systematic reviews summarising the best available evidence in accordance with standardised methodology. ${ }^{18}$ Unlike the National Institute for Health and Care Excellence (NICE), SIGN does not require a mandatory cost-effectiveness analysis. Recommendations graded A-D are based on a 
Table 2 Suggested risk stratification of levels of follow-up for 5 -year childhood cancer survivors after completion of treatment (reproduced from SIGN 132: Long term follow up of survivors of childhood cancer by kind permission) ${ }^{8}$

\begin{tabular}{|c|c|c|c|c|}
\hline Level & Treatment & Follow-up & Frequency & Examples \\
\hline 1 & $\begin{array}{l}\text { Surgery alone } \\
\text { Low-risk } \\
\text { chemotherapy }\end{array}$ & $\begin{array}{l}\text { Postal/ } \\
\text { telephone }\end{array}$ & 1-2 yearly & $\begin{array}{l}\text { Survivors of } \\
\text { Wilms' tumour } \\
\text { stage } \\
\text { I/II Langerhans cell } \\
\text { histiocytosis (single } \\
\text { system disease) } \\
\text { Germ cell tumours } \\
\text { (surgery only) }\end{array}$ \\
\hline 2 & $\begin{array}{l}\text { Chemotherapy } \\
\text { Cranial } \\
\text { radiotherapy } \\
\leq 24 \mathrm{~Gy}\end{array}$ & $\begin{array}{l}\text { Nurse/ } \\
\text { primary } \\
\text { care-led }\end{array}$ & 1-2 yearly & $\begin{array}{l}\text { Majority of } \\
\text { survivors }\end{array}$ \\
\hline 3 & $\begin{array}{l}\text { Any other } \\
\text { radiotherapy } \\
\text { (cranial } \\
\text { radiotherapy } \\
>24 \text { Gy) } \\
\text { Megatherapy } \\
\text { (ie, high-dose } \\
\text { chemotherapy) }\end{array}$ & $\begin{array}{l}\text { Medically } \\
\text { supervised } \\
\text { dedicated } \\
\text { long-term } \\
\text { follow-up } \\
\text { clinic }\end{array}$ & Annually & $\begin{array}{l}\text { Survivors of } \\
\text { Any brain tumour } \\
\text { Bone marrow } \\
\text { transplantation } \\
\text { Stage } 4 \text { patients of } \\
\text { any tumour type }\end{array}$ \\
\hline
\end{tabular}

SIGN, Scottish Intercollegiate Guidelines Network.

hierarchy of evidence from level 1 (meta-analyses, systematic reviews or randomised controlled trials) to level 4 (expert opinion).

\section{HOW DO I IMPLEMENT THESE GUIDELINES IN MY PRACTICE?}

- Primary care practitioners need to be alert to the many late organ toxicities incurred by increasing treatment intensity that may manifest decades after treatment. Lifelong surveillance for endocrinopathies, subfertility,

Box 1 Suggested members of the multidisciplinary follow-up team (with one member nominated as the key worker) (reproduced by kind permission from Scottish Intercollegiate Guidelines Network (SIGN) 132: Long term follow up of survivors of childhood ${\text { (ancer })^{8}}^{132:}$ (ang

Adult oncologist

Paediatric oncologist

Radiation oncologist

Paediatric neurosurgery

Paediatric endocrinologist

Paediatric neurologist

Specialist nurse/nurse practitioner

Clinical psychologist

General practitioner

Dentist

Optician

Social worker

\section{Clinical bottom line}

Childhood cancer survivors require lifelong monitoring to limit late consequences of their tumour and/or treatment, but the optimum service delivery model remains incompletely defined.

- While risk factors associated with certain late effects are known, many evolve over decades, with data interpretation confounded by retrospective and crosssectional study designs.

- Tertiary centres are developing one-stop age-appropriate multidisciplinary services for those at highest risk, but the majority will remain in primary and secondary care.

- All practitioners must thus be aware of consequences of cancer cure and thresholds for referral. In this respect, the SIGN guidance provides a helpful way forward for much needed service development and summarises the current evidence base.

- More prospective long-term morbidity outcome studies are required from current interventional trials to define the balance between improving survival with increasing treatment intensity and the quality of survivorship.

SPCs, cardiovascular disease, obesity and metabolic syndrome particularly in low-risk patients can only realistically occur in primary care, alongside supporting healthy lifestyle behaviours (including monitoring vitamin D status) and participation in secondary/tertiary follow-up. Young adult survivors may seek support for psychological illness or subfertility.

- Secondary care practitioners will monitor growth, puberty, thyroid function and neurocognitive development until adulthood, with appropriate specialist referral. Letters of support may be required for missed school attendances, statementing and disability living allowance applications. Adult physicians will be responsible for lifelong monitoring of cardiovascular disease, obesity, thyroid function, bone and sexual health, fertility and SPCs.

- Tertiary care practitioners should see all those at highest risk (brain, pelvic, bone tumour and transplant survivors) for hypothalamopituitary hormone dysfunction, fertility counselling, cardiac and cognitive assessments and psychological support. Clear end-of-treatment summaries with information regarding long-term surveillance needs and likely consequences are required. Implicit in the latter are the increased resources needed for such age-appropriate tertiary assessment and rehabilitation services.

\section{CONTROVERSIES AND UNADDRESSED ISSUES}

The level of care provided to childhood cancer survivors remains highly variable across the UK, ${ }^{19}$ and controlled trials on the optimum frequency, duration and 
quality of follow-up are still needed to determine the effectiveness of secondary prevention of, for example, congestive cardiac failure or hypocortisolaemic

\section{Box 2 Critical review}

- Timely update limited by absence of high-quality evidence for the cost effectiveness of the recommended lifelong three-tiered follow-up framework. Evidence graded mainly $C-D$ (none above B) consisting largely of uncontrolled qualitative studies of patient/family satisfaction, not morbidity or mortality. ${ }^{21}$

- Inherent bias in Guideline Development Group (GDG) composition-no renal, respiratory or neurology/ neuropsychology representatives with consequent omissions of important treatment-related renal, neurological and pulmonary toxicities (detailed in the UK CCSG Best Practice Statement).

- The Human Fertilisation and Embryology Act $(2008)^{22}$ governing storage and use of haploid gametes and embryos is not mentioned. It mandates personal (not proxy) consent, even in children; hence an intellectual ('Gillick') competency assessment is required. Blood-borne virus (HIV, hepatitis B \& C) testing prior to storage and written consent regarding use after death is also necessary.

- The endocrine and cognitive outcomes sections have not been updated (cited references are over 15 years old). As a result:

The cited data on pituitary craniopharyngiomas and hypothalamic obesity have been superseded by prospective outcome studies, ${ }^{23}$ retrospective reviews $^{24}$ and guidelines, ${ }^{25}$ not identified by the GDG search strategy.

The recommendation that all cranially irradiated patients receive annual cognitive assessments has never been achieved even in the context of a prospective trial. ${ }^{15}$

The perception that cranial irradiation per se causes eventual life-threatening pituitary deficits (eg, adrenocorticotropic hormone deficiency deficiency) persists from 1987 data on adult pituitary tumours; newer evidence suggests pituitary dysfunction is confined to GH deficiency and precocious puberty except in the presence of a suprasellar tumour, which is most likely causative. $^{26}$

Given the risk of radiation-associated subsequent primary cancers $(1 \%$ lifetime risk of thyroid cancer), the carcinogenicity of nuclear fallouts and an elevated thyroid-stimulating hormone $(\mathrm{TSH})^{27}$ and the long-term cardiovascular mortality risk of subclinical hypothyroidism, ${ }^{28}$ few clinicians would overlook screening for and treating compensated hypothyroidism (raised TSH, normal free $T_{4}$ ) after neck irradiation.
(Addisonian) crises. A pan-European prospective cohort study of $\sim 80000$ childhood cancer survivors (PanCareSurFup) is currently examining risk factors for cardiac disease, SPCs and late mortality. ${ }^{20}$ Several issues not discussed in the guideline are summarised in box 2 .

\section{FURTHER RESOURCES}

- Scottish Intercollegiate Guidelines Network (SIGN) 132: Long-term follow-up of survivors of childhood cancer http://www.sign.ac.uk/pdf/sign132.pdf

- UK Children's Cancer Study Group (UKCCSG) Best Practice Statement: Therapy-Based Long-Term Follow-Up (2nd ed.) http://www.cclg.org.uk/dynamic_files/LTFU-full. pdf

- National Cancer Survivorship Initiative (NCSI) website http://www.ncsi.org.uk/

- Pan-European Network for Care of Survivors after Childhood and Adolescent Cancer (PanCare) http://www. pancare.eu/en/

- British Fertility Society (BFS) Consultation Paper on Fertility in Childhood Cancer http://www.britishfertilitysociety.org.uk/ practicepolicy/documents/fccpaper.pdf

Acknowledgements We would like to thank SIGN for their kind permission in the use of table 2 and box 1 for this review.

Contributors H-WG wrote the initial manuscript draft, and HAS provided significant editions and useful expert opinion. Competing interests None.

Provenance and peer review Commissioned; externally peer reviewed.

Open Access This is an Open Access article distributed in accordance with the Creative Commons Attribution Non Commercial (CC BY-NC 3.0) license, which permits others to distribute, remix, adapt, build upon this work noncommercially, and license their derivative works on different terms, provided the original work is properly cited and the use is non-commercial. See: http://creativecommons.org/licenses/by$\mathrm{nc} / 3.0 /$

\section{REFERENCES}

1 Gatta G, Capocaccia R, Stiller C, et al. Childhood cancer survival trends in Europe: a EUROCARE Working Group study. J Clin Oncol 2005;23:3742-51.

2 Office for National Statistics. Cancer statistics registrations: registrations of cancer diagnosed in 2009, England (MB1 40). London: Office for National Statistics, 2011.

3 Stiller CA. Childhood cancer in Britain: incidence, survival, mortality. Oxford: Oxford University Press, 2007.

4 Skinner R, Wallace WH, Levitt G. Long-term follow-up of children treated for cancer: why is it necessary, by whom, where and how? Arch Dis Child 2007;92:257-60.

5 Oeffinger KC, Mertens AC, Sklar CA, et al. Chronic health conditions in adult survivors of childhood cancer. $N$ Engl J Med 2006;355:1572-82.

6 Department of Health, Macmillan Cancer Support, NHS Improvement. Living with and beyond cancer: taking action to improve outcomes. London: National Cancer Survivorship Initiative (NCSI), Department of Health, 2013.

7 Wallace WH, Blacklay A, Eiser C, et al. Developing strategies for long term follow up of survivors of childhood cancer. BMJ 2001;323:271-4. 
8 Scottish Intercollegiate Guidelines Network (SIGN). Long term follow up of survivors of childhood cancer. Edinburgh: SIGN, 2013. (SIGN publication no. 132).

9 Skinner R, Wallace WHB, Levitt GA. eds. Therapy based long-term follow-up. 2nd edn. UK Children's Cancer Study Group (UK CCSG) Late Effects Group, 2005.

10 Reulen RC, Frobisher C, Winter DL, et al. Long-term risks of subsequent primary neoplasms among survivors of childhood cancer. JAMA 2011;305:2311-19.

11 Multidi sciplinary Working Party convened by the British Fertility Society. A strategy for fertility services for survivors of childhood cancer. Hum Fertil (Camb) 2003;6:A1-A39.

12 Gan HW, Spoudeas HA. Preserving reproductive capacity in young boys with cancer. Trends Urol Men's Health 2013;4:8-12.

13 Bahadur G, Ozturk O, Muneer A, et al. Semen quality before and after gonadotoxic treatment. Hum Reprod 2005;20:774-81.

14 Steffens M, Beauloye V, Brichard B, et al. Endocrine and metabolic disorders in young adult survivors of childhood acute lymphoblastic leukaemia (ALL) or non-Hodgkin lymphoma (NHL). Clin Endocrinol (Oxf) 2008;69:819-27.

15 Bull KS, Spoudeas HA, Yadegarfar G, et al. Reduction of health status 7 years after addition of chemotherapy to craniospinal irradiation for medulloblastoma: a follow-up study in PNET 3 trial survivors on behalf of the CCLG (formerly UKCCSG). J Clin Oncol 2007;25:4239-45.

16 Kennedy C, Bull K, Chevignard M, et al. Quality of Survival and Growth in Children and Young Adults in the PNET4 European Controlled Trial of Hyperfractionated Versus Conventional Radiation Therapy for Standard-Risk Medulloblastoma. Int J Radiat Oncol Biol Phys 2014;88: 292-300.

17 Sklar CA, Mertens AC, Mitby P, et al. Risk of disease recurrence and second neoplasms in survivors of childhood cancer treated with growth hormone: a report from the Childhood Cancer Survivor Study. J Clin Endocrinol Metab 2002;87:3136-41.
18 Scottish Intercollegiate Guidelines Network (SIGN). SIGN 50: A guideline developer's handbook. Edinburgh: SIGN, 2011.

19 Taylor A, Hawkins M, Griffiths A, et al. Long-term follow-up of survivors of childhood cancer in the UK. Pediatr Blood Cancer 2004;42:161-8.

20 Hjorth L, Kvarnstrom E. Pancare Childhood and Adolescent Cancer Survivor Care and Follow-up Studies. 2013. [cited 20132 December 2013]; http://www.pancaresurfup.eu

21 Heirs M, Suekarran S, Slack R, et al. A systematic review of models of care for the follow-up of childhood cancer survivors. Pediatr Blood Cancer 2013;60:351-6.

22 Human Fertilisation and Embryology Act 1990 (modified 2008). London, UK: HMSO, 2008.

23 Muller HL, Gebhardt U, Teske C, et al. Post-operative hypothalamic lesions and obesity in childhood craniopharyngioma: results of the multinational prospective trial KRANIOPHARYNGEOM 2000 after 3-year follow-up. Eur J Endocrinol 2011;165:17-24.

24 Karavitaki N, Brufani C, Warner JT, et al. Craniopharyngiomas in children and adults: systematic analysis of 121 cases with long-term follow-up. Clin Endocrinol (Oxf) 2005;62:397-409.

25 Spoudeas HA, Albanese A, Saran F, et al. Chapter OneCraniopharyngioma. In: Spoudeas HA, Harrison B. eds. Paediatric endocrine tumours: a multidisciplinary consensus statement of best practice from a working group convened under the auspices of the British Society for Paediatric Endocrinology \& Diabetes (BSPED) and United Kingdom Children's Cancer Study Group (UKCCSG) (rare tumour working groups). 1st edn. Crawley, UK: Novo Nordisk Ltd., 2005:16-46.

26 Darzy KH, Shalet SM. Hypopituitarism following radiotherapy. Pituitary 2009;12:40-50.

27 Jereczek-Fossa BA, Alterio D, Jassem J, et al. Radiotherapy-induced thyroid disorders. Cancer Treat Rev 2004;30:369-84.

28 Rodondi N, den Elzen WP, Bauer DC, et al. Subclinical hypothyroidism and the risk of coronary heart disease and mortality. JAMA 2010;304:1365-74. 